OPEN ACCESS

Edited by:

Cheryl J. Craig,

Texas A\&M University, United States

Reviewed by:

Elisabete dos Santos Freire, Universidade São Judas Tadeu, Brazi

Rosa Maria Rodríguez Izquierdo, Universidad Pablo de Olavide, Spain

*Correspondence:

Miguel A. Santos Rego miguelangel.santos@usc.es

Specialty section: This article was submitted to

Teacher Education,

a section of the journa

Frontiers in Education

Received: 14 September 2020 Accepted: 22 March 2021

Published: 12 April 2021

Citation:

Santos Rego MA, Mella Núñez l, Naval $C$ and Vázquez Verdera V (2021) The Evaluation of Social and Professional Life Competences of University Students Through

Service-Learning

Front. Educ. 6:606304.

doi: 10.3389/feduc.2021.606304

\section{The Evaluation of Social and Professional Life Competences of University Students Through Service-Learning}

\author{
Miguel A. Santos Rego ${ }^{1 *}$, Ígor Mella Núñez ${ }^{1}$, Concepción $\mathrm{Naval}^{2}$ and \\ Victoria Vázquez Verdera ${ }^{3}$
}

\begin{abstract}
${ }^{1}$ Research Group ESCULCA, Department of Pedagogy and Didactics, University of Santiago de Compostela, Santiago de Compostela, Spain, ${ }^{2}$ Character, Education and Citizenship Research Group, Department of Research Theory and Methods in Education and Psychology, University of Navarra, Pamplona, Spain, ${ }^{3}$ Research Group on University Pedagogy and Teaching-Learning Strategies (GIPU-EA), Department of Education Theory, University of Valencia, Valencia, Spain
\end{abstract}

The view previously held in the university regarding teaching-learning processes has changed significantly over the past few years. Undoubtedly, in the case of Europe, this change of pedagogical model has gone hand in hand with the creation of the European Higher Education Area (EHEA). Some of the pivotal areas of EHEA are the independent work of the individual student, the social dimension of learning, and the acquiring of skills, which are not reduced to the mere technical and/or subject matter knowledge. Generic competences and the so-called "soft skills" have also become important, given their significant contribution to the students' academic, personal, social, and professional development. Predictably, within this framework, new methodologies appear, in line with this educational focus on competences; among these new methodologies include service-learning (SL). It basically consists of introducing a community service into the traditional academic and curricular tasks thereby seeking a better relevance and applicability in the learning processes. This article analyzes the way in which SL contributes to the acquisition, by university students, of a certain skill set which is useful for their social and professional life. To this end, we used a quasi-experimental design, which included pretest and posttest assessments based on a total sample of 1,153 students (789 SL students and 364 non-SL students). The used questionnaire evaluates three important components relevant for the purpose of the present article (perception of the university education, social participation and civicsocial competences). The conclusion is that students involved in SL not only show a more positive evolution, but also obtain better results after the projects are completed (regarding satisfaction with the training, and social participation). By the same token, not all students included in the experimental group achieve homogeneous results; the differences are according to variables such as gender, the cycle/year they are enrolled in, 
area of study or whether or not they previously participated in university service activities. Finally, we observe that this methodology is capable of approaching university education in a holistic way by asserting cross-section type learning processes likely to be useful in the transition from the students' academic to their professional life.

Keywords: service-learning, higher education, evaluation, competences, soft skills, employability, social capital

\section{INTRODUCTION}

Since the advent of the new century, we have witnessed a continuous appeal for a change of focus, or of paradigm, with regard to the optimization of learning processes, especially in the case of students in higher education. This call, expressed more acutely in academic forums and civil society instances was not unconnected to the fact that we live in a knowledge society, in which the impact of digital technology makes a difference in productivity patterns and development indicators (Etzkowitz et al., 2012).

Within such a context, the university again lays claim to being the most eminent and natural motor for the production, transmission, and transfer of knowledge. This is sufficient reason to start giving proper attention (thereby correcting some inertias of the past) to the skills and capabilities of one's students in order to ensure a better personal development and a progressive adaptation to constantly changing professional realities (Välimaa and Hoffman, 2008).

Although the interest in the particular dynamics of this society of learning and/or knowledge is relatively recent, the reflection about it and the very reality it refers to are not. In fact, the origin of the concept is ascribed to Professor Robert E. Lane from Yale University, in the 1960s (Lane, 1966; Välimaa and Hoffman, 2008). The changes which took place then (late 1960s and early 1970s) led, according to Delanty (2003), to the transition from what can be labeled as a "professional society", based upon industry and a utilitarian type of knowledge, to a post-industrial society much more oriented toward services.

Hence, as the influence of the society of knowledge grew, higher education also saw its traditional functioning patterns redesigned, both in matters of its social component and at a more strictly academic level. It was the Commission of the European Communities (2003) itself, which pointed to the existing link between the new model of social organization and the surging of new expectations from the university which gradually transformed into different educational necessities. In this paper we argue that, without minimizing the importance of the technical domain in each degree or academic title, one has to place value on the cross-section competences in the training of students and to enhance the opportunities of lifelong learning. Only in this way can one ensure that students will possess the necessary competences for an appropriate personal, professional, and social development, in an environment marked by change and uncertainty (Santos Rego, 2016).

Having said all the above, we can confidently state that the transmission of exclusively technical learning, articulated around theoretical contents and knowledge, becomes insufficient. This has given rise to a new educational model within the university, made possible by the focus on skill-based learning, skills becoming the point of reference meant to lead the training processes. One must contend, therefore, with one of the most stringent requirements faced by 21 st century universities, referring, as stated by the Council of the European Union (2010) to the importance of students acquiring the competences likely to allow for the improvement of their employment prospects and to contribute to their personal fulfillment, social inclusion and active citizenship, without overlooking their capacity to organize themselves when faced with realities much less predictable than ever before.

We should remember that, in Europe, the groundwork for the gradual visibilization of the new focus was laid by the Tuning Project (González and Wagenaar, 2003), which coincided with the progressive construction of the European Higher Education Area and the adoption of the European Credit Transfer System (ECTS). What one proposed back then was that, pragmatically speaking, the concept of competences had to be understood broadly enough, as being acquired by the student throughout the learning process and the result of a combination of knowledge, understanding, skills and abilities. At the same time, a differentiation was made between specific competences (those related to the knowledge of a particular academic subject) and generic competences (transferable to any academic title) with the latter being those necessary for an appropriate professional development of students and also those likely to foster a type of learning which must be ongoing and/or lifelong (Council of the European Union, 2010).

On the other hand, one has to acknowledge that the important role which must be assigned to those cross-section and lifelong competences does not only correspond to a renewed vision of the university, given that those who employ university graduates (companies, organizations etc.) apart from the specific knowledge of their respective field, value another type of competences, both intellectual and personal. Without looking too far, it would be the case in communicational or teamwork skills (Wye and Lim, 2009). It is undeniable that the labor market requires technical knowledge within a real setting, but this is not the only requirement and sometimes it is not even crucial. Many organizations include in their selection or promotion grids other soft skills, of cross-section nature and linked, to a very large extent, to the social dimension of learning (Succi and Canovi, 2019).

It was precisely in the last decade that a heated debate around the concept of soft skills has been seen. There can be little doubt about the need for those skills to be promoted and cultivated, even if the problem, as usual, consists of the lack of an adequate conceptualization thereby resulting in a certain degree of ambiguity in its significance. When speaking 
about soft skills, one points to a variety of qualities, features, values, attributes which also include some emotional aspects. They consist, ultimately, of a combination of personality traits, objectives, propositions, motivations and preferences of the persons and they are highly valued not only within educational contexts, but also on the labor market, as well as in other segments of daily life, even becoming guarantors of success (Heckman and Kautz, 2012).

The origin of the term "soft skills" dates back to some United States Armed Forces documents from 1972 (Touloumakos, 2011). Over these almost five decades, the term has encompassed different aspects, including: professionalism and work ethic; capacity of working and learning; decision making; creativity and innovation; interpersonal, social and teamwork abilities; communication and conflict resolution abilities; capacity of managing information and technology; or leadership skills (Andrews and Higson, 2008; Lazarus, 2013).

Delving more into the expression itself, it seems important that soft skills are considered actions, which entail a look at the person who acts (Matteson et al., 2016). These abilities are presented as generic properties which can be acquired and exercised in various contexts, transversally, and which continue to present difficulties in their analysis. Among these soft skills, preferences are given to those that are useful for social and professional life, the main axis around which the present article revolves. An indicative sample is the importance of the research on the promotion of interpersonal, social and team skills (Bancino and Zevalkink, 2007). The same could be said about the stimulation of communication skills (Mitchell et al., 2010) as well as of the negotiation and conflict resolution skills (Succi and Canovi, 2019).

The role of this type of learning processes in university education is even more relevant in the present-day society and professional reality (Naval and Arbués, 2018), given, among other reasons, the new functions which UNESCO (1998) ascribed to higher education in the 21 st century, three of which we wish to highlight here:

- To train highly qualified graduates and responsible citizens who, through a series of theoretical and practical competences, would attend to the needs of society and actively participate in social life.

- To protect society's values, ensuring that those values, which promote a democratic and critical citizenship, are instilled in the youngest generation.

- To contribute to the understanding, interpretation, preservation, reinforcement, promotion and transmission of regional, national and international, as well as historical cultures taking as a reference a plural context, one of cultural diversity.

These ideas make more sense, in a socioeconomic moment as the present one (Naval and Arbués, 2016); it seems logical that the universities' collaboration should be requested in order to tackle this situation while taking into account the competences which students would need in their personal and professional life. Most certainly, the mission of higher education is social, cultural and that of transferring knowledge.

For this reason, numerous methodologies have taken root in the educational dynamics of the university over the past few years, in order to fit in with a model in which the factor of interest is constituted by the students' effort and the construction of learning processes which would be useful for the social and professional contexts in which one has to work. One of the methodologies which shows more potential in this regard is service-learning (SL). In the most elementary sense, it means introducing community service into the traditional academic and curricular tasks, including a strong component of continuous reflection which allows establishing mutual relationships between academic learning and action within community environment. More specifically, "it is conceptualized within experience-based education and is characterized by: (a) student protagonism; (b) addressing a real need; (c) connection to curricular objectives; (d) execution of the service project and (e) reflection" (Naval et al., 2011, p. 88).

Given its peculiar pedagogical features, we agree with Butin (2003) in suggesting that we are dealing with a shift in the patterns, from the passive and that of receiver of information to the active, where direct contact with the real world, as well as the relationship established between university and community allow for the connection between theory and practice, moving away from an instrumental vision of education. In this way, it directly affects the students' attitude toward the training they receive, given that the acquisition of practical knowledge constructed around their own experience shows clear repercussions in their levels of satisfaction, especially given the perceived usefulness of their learning processes (Thamwipat et al., 2018). From this point of view, students participating in SL report positive emotions such as interest, enthusiasm, inspiration and determination (Opazo et al., 2018); they also state that the educational experience provides them with satisfaction, commitment and growth (Watson et al., 2018); and they see their motivation and perception of self-efficacy transcend (Gonsalves et al., 2019).

The above is due, to a large extent, to the connections and reciprocity relationships established between university and community, because, in the latter, the students find the applicability of what they have learned, besides acquiring knowledge rooted outside of the classroom and the campus, strongly contextualized and located within the social dynamics (McIlrath, 2012). A special mention should be made of the capacity to develop civic and social competences, considered to be of great importance in order to guarantee a holistic development of the students (Jagla and Tice, 2019; Succi and Canovi, 2019; Cohen, 2020). Furthermore, as suggested by Bringle and Clayton (2012), SL is different from other methodologies in that, by considering civic learning as a top-level objective, it is directly connected to both the professional reality and the deontological responsibilities and does not limit itself to exclusively promoting cognitive-type learning.

Evidence of this is provided by the annual questionnaire distributed in the United States by Campus Compact (2015), in which the universities belonging to this network stated that SL allowed them to achieve visible levels of civic commitment in 
their students. In particular, they acknowledge results in fields such as civic and democratic learning ( $81 \%$ of the institutions), social commitment to diversity $(76 \%)$, orientation toward social justice (64\%) or global learning (64\%). Furthermore, Moely et al. (2002a) discovered that students participating in SL scored higher than their peers did in different dimensions of Civic Attitudes and Skills Questionnaire (CASQ): civic actions, interpersonal and problem resolution skills, political awareness, leadership competences, and attitudes of social justice. Another example is the study carried out by Einfeld and Collins (2008), in which evidence was provided for improvement in the sphere of social justice, especially with regard to inequality; development of multi-cultural skills; and civic involvement, which is understood as the exercise of an active citizenship and the commitment to community service.

The previous arguments are certainly strengthened by taking into account the vision of Opazo et al. (2015), who insisted on the opportunities provided by SL in putting different groups of persons who otherwise would not have the possibility to share time, thoughts or experiences into contact with each other. The authors also emphasized that these projects provided opportunities to know and acknowledge different social problems and real needs, thereby stimulating social commitments. Said commitments consequently lead to an impact in the levels of political and social participation by young people, its contribution being crucial in terms of motivation, given that it is through one's own involvement in social matters that the interest for public life is increased (Ugarte and Naval, 2010).

However, the concern for public matters must not be reduced to mere political participation, given that it also includes the attitudes, values and intentions to help and serve in the development of the community. There are many studies which prove the good contribution of SL in this regard and demonstrate an improvement in the students' predisposition to get involved in community service initiatives such as volunteer work, as well as in the perception of their own social responsibility (Markus et al., 1993; Fenzel and Peyrot, 2005).

All of the above shows SL as a methodology capable of coping with a new university model, in which the student's independent work is the basis of the teaching-learning processes and contact with day-to-day reality allows for acquiring skills which would guarantee an appropriate personal, social and professional transition of the graduates. However, what we are aiming for is to demonstrate this potential as part of a rigorous methodological approach, under a strongly contextualized view in the Spanish university system and, by extension, in the European university system. It is also important the different existing conceptions for the topics into which this work was organized, such as SL or soft skills in university education, as well as their value on the labor market and, moreover, in different societies (Santos Rego et al., 2020b). Precisely for this reason, our research question was: Is SL a sufficiently adequate and epistemically sound methodology to ensure the development of the relevant soft skills that can be useful to university students for their personal and professional development?

The importance of evaluating the relationship between SL and the development of social and professional competences has to do with the uniqueness of this methodology. In this regard, Bringle and Clayton (2012) stated that, while other educational strategies sought to promote academic learning (with a focus on content) and cognitive development, SL also aimed at achieving greater civic learning. It also promotes and strengthens the links of this civic learning with professional education, especially in relation to the ethical responsibilities of practice (Bringle and Clayton, 2012). In short, it is a methodology that enables a more situated learning experience by linking university students with community environments, beyond academic development, and influencing on other generic and transversal learnings.

In the case of the Spanish university system, we should study the way in which students develop social and professional competences, especially when active methodologies such as SL are used. In terms of social competences, the involvement of Spanish youth in associations and organizations can be greatly improved (Jover, 2016; Santos Rego et al., 2018). Moreover, if we focus on professional competences, the data on youth unemployment in Spain are alarming $(39.9 \%$ according to the Eurostat barometer, 2021 ${ }^{1}$ ).

Our motivation involves the intention of addressing a gap that persists in research and that, particularly in Europe, translates into a lack of attention to the links between SL and the new training models that have emerged with the consolidation of the EHEA, as is the case of the generic competences proposed by the Tuning Project (González and Wagenaar, 2003). The study is therefore aimed at analyzing the differences between university students participating in SL projects and those following an usual formative process, while addressing issues such as how university formation is viewed (in terms of motivation, satisfaction and uncertainty about one's professional future) as well as social participation, and the development of civic and social competences.

\section{MATERIALS AND METHODS}

The survey carried out aims to establish whether there are differences regarding the development of certain competences, which are considered to be of interest for an adequate personal and professional progress of university students, taking into account their participation in SL courses. In order to achieve this aim, we proceeded in accordance with a quasi-experimental design, in which the independent variable was given by the participation in the various SL experiences. More specifically, students participating in these projects made up the experimental group (EG), whilst those who followed a more conventional methodology acted as a control group (CG).

At the same time, another objective was to know the profile of students who were following the SL methodology where the impact was at its greatest, for which purpose we analyzed the differences within the EG according to some variables: gender, cycle of studies, area of study (grouping together, on the one hand, students of Social and Legal Sciences, and Arts and Humanities; and, on the other hand, students of Health Sciences,

\footnotetext{
${ }^{1}$ https://ec.europa.eu/eurostat/databrowser/view/UNE_RT_M_custom_676480/ default/table?lang=en
} 
and Engineering and Architecture) as well as prior participation to other community service activities promoted by the university.

\section{Participants}

The sample was made up of 1,153 university students, out of whom 789 (68.4\%) participated in SL projects, whilst the remaining $364(31.6 \%)$ followed a conventional methodology. In particular, the data was collected within the framework of the subjects taught at the University of Santiago de Compostela, which implemented SL projects during the 2016-2017 and 20172018 academic years. The results of 32 SL projects were evaluated (19 in the first year of the study; 13 in the second year); they were developed in different university degree programs under an institutional call for support for the implementation of SL.

From these subjects, students involved in SL projects made up the EG, whereas the CG was made up of those engaged in the more conventional academic tasks. This is the difference between the two groups: those who participate in SL learn the basic contents of the subject while being involved in addressing a social need in the university environment. On the other hand, the CG followed the normal classroom dynamics, i.e., expository and interactive classes or laboratory sessions. In short: in both cases the same contents of the subjects are worked on, but in SL the theory-practice link is more explicit, given the connection between learning and a social or community problem.

The students' ages ranged between 19 and 51 years, although $88.4 \%$ of them were in the $18-24$ age segment, with an average age of 21.84 years. Out of them, $75 \%$ are women and $25 \%$ men. As far as academic years are concerned, they were homogeneously distributed across the 4 years of graduate study: $28.4 \%$ were in the first year, $21.9 \%$ in the second, $25.3 \%$ in the third, and $24.4 \%$ in the fourth. The majority were enrolled in Social and Legal Sciences (80.4\%), followed by Health Sciences (15.8\%), Arts and Humanities (2.8\%), and Engineering and Architecture $(0.8 \%)$. Finally, only 18 students $(1.6 \%)$ indicated that they were part of a mobility agreement (Erasmus, SICUE-Séneca and bilateral agreements).

\section{Instrument}

This study made use of the Questionnaire on University Students' Civic and Social Competences and Self-Efficacy (CUCOCSA) (Santos Rego and Lorenzo, 2018). It is a questionnaire consisting of three open and 10 closed questions. The closed questions, for their part, are divided into dichotomic items, multiple choice single select questions, and scalar items. As far as their content is concerned, there are questions referring to the personal and academic biography of the student: age, gender, degree and academic year of enrollment, faculty, campus, participation in mobility programs, in projects involving some form of community service and in SL courses. Thereupon four scales are presented on: university training, social participation, civicsocial competences, and perceived self-efficacy. The results of the present study come from the first three scale. The perceived self-efficacy was not used.

As far as the validity of the instrument's content is concerned, we used an external validation procedure, carried out by five judges, experts in the areas of knowledge which were relevant to the study. Subsequently, in order to test the reliability and validity of the scales, we carried out an exploratory and then a confirmatory factor analysis (CFA) (Mella, 2019). The psychometric analysis of the scales was carried out with a total of 996 university students, which was randomly distributed in two sub-samples (the first made up of 500 students and the second of 496).

With sub-sample 1 (calibration sample), we performed an exploratory factor analysis (EFA) as well as the calculation of the factors' reliability by means of Cronbach's $\alpha$, thereby establishing the dimensionality of the scales, using the Principal Components extraction method and a Varimax rotation. The KMO tests $=0.846$ and $\chi^{2}(190)=2,833.81, p<0.001$, reported good sampling adequacy and a significant correlation between items, respectively.

With sub-sample 2 (validation sample), we carried out a CFA using the AMOS 20 Statistics Package, with the purpose of checking whether the factorial structure previously obtained in the EFA adequately represented the information provided by the data, obtaining a good fit in all the cases. We will now go on to explain the factorial structure of each one of the scales:

\section{University Training Scale}

Its objective was to analyze the students motivation and perception with regard to the training they receive in the university. In order to build it, we used as a basis the Evaluation System for Experiential Educational Programs (ESEE) designed by Furco (1995), a protocol for the evaluation of experiential education and, more specifically of SL projects. The scale is made up of seven items (from strongly disagree to strongly agree) out of which the EFA distinguishes three significant factors: link between the subjects and real life $(\alpha=0.79)$, satisfaction with the training $(\alpha=0.70)$, and uncertainty about the future $(\alpha=0.50)$, which explained a variance of $66.11 \%$ and showed a good internal consistency.

\section{Social Participation Scale}

It seeks to measure the students' social involvement. They are asked to assess their degree of participation in civic matters, be they pertaining to the university or what is exterior to it. In order to build it, we took as a reference the Civic-Minded Graduate Scale of the Indiana University-Purdue University Indianapolis (Steinberg et al., 2011; Pike et al., 2014). It consists of five items (from never to on a weekly basis) which, upon applying the EFA, were grouped into a factor that explained a variance of $42.39 \%$, showing a good internal consistency $(\alpha=0.60)$.

\section{Civic and Social Competence Scale}

This third scale includes a set of items whose focus is the analysis of the degree to which students believe they possess a series of competences connected to civic and social matters. Four were the instruments serving as a reference for its construction: the CASQ (Moely et al., 2002b); a self-evaluation scale on the development of generic competences (Santos Rego et al., 2018); the Public Affairs Scale-Short Survey (PAS-SS) (LevesqueBristol and Richards, 2014); and the Evaluation System for Experiential Educational Programs (ESEE) by Furco (1995). It consists of a total of 20 items which, following the initial extraction, are organized into four significant factors that explain 
a variance of 50.96\%: personal behavior $(\alpha=0.79)$, leadership ( $\alpha=0.72)$, intercultural competence $(\alpha=0.73)$, and teamwork and relationship with others $\alpha=0.70)$.

\section{Procedure}

The instrument was distributed during the 2016-2017 and 2017-2018 academic years. This questionnaire was applied in a pretest situation, before the start of the SL projects, as well as at their end (posttest), in each case before the final exam for the subject. Given its estimated answering time of 10-15 min, it was carried on on-site, guaranteeing the confidentiality of the collected data (anonymity, system of codification and custodianship).

At the beginning of the study, the governing team of the University of Santiago de Compostela was also informed of the aim of the research project and of the procedure which was to be followed. In applying the instrument, we followed the recommendations of the University of Compostela's Bioethics Committee and of the Helsinki Declaration, complying with the stipulations which, in the case of Spain, are laid down in the Organic Law 3/2018, of December 5, on Data Protection and Guarantee of Digital Rights.

\section{Data Analysis}

To begin with, in order to calculate the dimensionality of the three scales, an EFA was carried out, in order to obtain the structural validity and the reliability of each one of them. The information stemming from the EFA was subsequently verified by carrying out a CFA, as presented in the previous section (Mella, 2019). This procedure is known as "cross-validation" (Cudeck and Browne, 1983).

Subsequently, comparison tests were carried out between the pretest and posttest, both for those students who were involved in a SL course during the academic year (EG) and for those who were not (CG). The dependent variables taken into account were the factors obtained in the EFA and validated in the CFA. The aim was to know the impact generated by the involvement in SL in the development of three of the dimensions making up the instrument (perception of the university education, social participation, and civic-social competences). Subsequently, by means of a comparison test, we studied the differences between both groups in the factor scores obtained at the end of the academic year, in order to find out whether any of them showed a higher level of development.

Finally, for each one of the factors, the profile of the students participating in SL activities were compared. For this purpose, the scores obtained by these students in the posttest phase were contrasted according to gender, cycle of studies, area of study, and previous participation in service activities promoted by the university. The significance level chosen for all the tests was $\alpha=0.05$, and all the analyses were carried out with the SPSS v. 24 .

\section{RESULTS}

In order to present the results obtained in each one of the scales, one starts by presenting the scores obtained (EG and CG) in pretest and posttest, so as to analyze the evolution of both groups during the SL projects. Then, the differences between the two groups in the posttest are identified, the intended purpose being to assess the possible impact of the fact of participating or not in SL on the measured variables. Finally, we present the differences occurring within the EG's scores in the posttest stage.

\section{University Training}

With regard to the students' perception of the training received at university (Tables 1, 2), we noted significant improvements in the EG, where, after the conclusions of the SL project, a greater degree of satisfaction concerning the connection between the studied subject and real life was evident. This satisfaction also extends to the training they receive. In the case of the CG, not only the lack of improvement in the studies is striking, but also the fact that these students show higher levels of uncertainty about the future.

Besides a better evolution between the pretest and posttest stages, the EG is significantly different from the CG in matters of their satisfaction with their university education (Table 3). What this indicates is that students who participate in the SL projects conclude their studies with a greater satisfaction with the training they received in the university, both in terms of its usefulness for their life and for their future profession.

Nevertheless, not all students involved in SL scored homogeneously on this scale. Looking at the profile of the

TABLE 1 | Pretest/posttest differences in the experimental group's (EG's) perception of the university training.

\begin{tabular}{|c|c|c|c|c|c|c|c|}
\hline \multirow[t]{3}{*}{ Factor } & \multicolumn{7}{|c|}{ Experimental group } \\
\hline & \multicolumn{2}{|c|}{ Pretest } & \multicolumn{2}{|c|}{ Posttest } & \multirow[t]{2}{*}{$t$} & \multirow[t]{2}{*}{$\mathrm{d} f$} & \multirow[t]{2}{*}{$p$} \\
\hline & Mean & SD & Mean & SD & & & \\
\hline $\begin{array}{l}\text { Connection } \\
\text { between the } \\
\text { studied subject and } \\
\text { real life }\end{array}$ & 4.62 & 0.489 & 4.69 & 0.476 & -3.725 & 778 & 0.000 \\
\hline $\begin{array}{l}\text { Satisfaction with } \\
\text { the training }\end{array}$ & 3.37 & 0.834 & 3.43 & 0.850 & -2.278 & 779 & 0.023 \\
\hline $\begin{array}{l}\text { Uncertainty about } \\
\text { the future }\end{array}$ & 3.06 & 0.940 & 3.12 & 0.988 & -1.480 & 771 & 0.139 \\
\hline
\end{tabular}

TABLE 2 | Pretest/posttest differences in the control group's (CG's) perception of the university training.

\begin{tabular}{|c|c|c|c|c|c|c|c|}
\hline \multirow[t]{3}{*}{ Factor } & \multicolumn{7}{|c|}{ Control group } \\
\hline & \multicolumn{2}{|c|}{ Pretest } & \multicolumn{2}{|c|}{ Postest } & \multirow[t]{2}{*}{$T$} & \multirow[t]{2}{*}{ df } & \multirow[t]{2}{*}{$p$} \\
\hline & Mean & SD & Mean & SD & & & \\
\hline $\begin{array}{l}\text { Connection } \\
\text { between the } \\
\text { studied subject and } \\
\text { real life }\end{array}$ & 4.69 & 0.393 & 4.69 & 0.514 & -0.102 & 358 & 0.919 \\
\hline $\begin{array}{l}\text { Satisfaction with } \\
\text { the training }\end{array}$ & 3.16 & 0.854 & 3.23 & 0.882 & -1.777 & 357 & 0.076 \\
\hline $\begin{array}{l}\text { Uncertainty about } \\
\text { the future }\end{array}$ & 3.06 & 0.916 & 3.16 & 1.001 & -2.026 & 351 & 0.044 \\
\hline
\end{tabular}


TABLE 3 | Differences between the EG and the CG in the perception of the university training (posttest).

\begin{tabular}{|c|c|c|c|c|c|}
\hline \multirow[t]{2}{*}{ Factor } & \multicolumn{2}{|c|}{$\begin{array}{l}\text { Levene's test for } \\
\text { equality of variances }\end{array}$} & \multirow[t]{2}{*}{$t$} & \multirow[t]{2}{*}{$\mathrm{d} f$} & \multirow[t]{2}{*}{$\begin{array}{l}\text { Bilateral } \\
\text { sig. }\end{array}$} \\
\hline & $F$ & Sig. & & & \\
\hline $\begin{array}{l}\text { Connection between the } \\
\text { studied subject and real life }\end{array}$ & 1.112 & 0.292 & -0.207 & 1,145 & 0.836 \\
\hline $\begin{array}{l}\text { Satisfaction with the } \\
\text { training }\end{array}$ & 0.589 & 0.443 & -3.672 & 1,143 & 0.000 \\
\hline Uncertainty about the future & 0.390 & 0.532 & 0.600 & 1,131 & 0.548 \\
\hline
\end{tabular}

students, we observed within the EG some variations in the scores obtained. Firstly, the women differentiated from men in that they had a more positive appraisal of the connection between academic subject and real life $\left(M_{\text {Women }}-M_{\text {Men }}=0.17\right.$, $p=0.000)$. In the same factor, the students who had already participated in university service activities scored higher, marking differences from those who had never been involved in this type of initiatives $\left(M_{\text {Previous service }}-M_{\text {No }}\right.$ Previous service $=0.10$, $p=0.005)$.

Finally, in matters of the area of study, there are differences concerning the satisfaction with training. Students of Health Sciences and Engineering-Architecture who got involved in SL ended their participation in these projects markedly more satisfied with the training they received in the university ( $M_{\text {Health Sciences and Engineering-Architecture }}-M_{\text {Social-Legal Sciences and }}$ Arts-Humanities $=0.59, p=0.000)$.

\section{Social Participation}

In the second of the scales, when measuring the levels of participations in activities of social outreach and volunteering, both in and out of the university, both groups shared a significant evolution between the two applications of the instrument (Tables 4, 5). However, we must pay due attention in the means obtained here, which are quite low, reflecting a rather sporadic participation of the university students in volunteer work or community service activity.

Besides the evolution witnessed by all the students throughout the evaluated period, we also found differences between them in matters of their participation in SL projects (Table 6). Thus, in posttest stage, those who were involved in these experiences showed higher levels of participation in other service areas.

Again, there were significant differences within the EG at the end of the projects. In this case, the variables which had an influence were the cycle of studies and the area of study. As far as the cycle is concerned, students of the first two academic years showed higher levels of social participation and involvement in volunteering when they end the SL project $\left(M_{\text {First cycle }}-M_{\text {Second cycle }}=0.10, p=0.027\right)$. The Social-Legal Sciences and Arts-Humanities students also finished their involvement in SL showing a higher level of participation in social outreach activities than students from the areas of Health Sciences and Engineering-Architecture ( $M_{\text {Social-Legal }}$ Sciences and Arts-Humanities $-M_{\text {Health }}$ and Engineering-Architecture $=0.21, p=0.000)$.
TABLE 4 | Pretest/posttest differences within the experimental group in matters of social participation.

\begin{tabular}{|c|c|c|c|c|c|c|c|}
\hline \multirow[t]{3}{*}{ Factor } & \multicolumn{7}{|c|}{ Experimental group } \\
\hline & \multicolumn{2}{|c|}{ Pretest } & \multicolumn{2}{|c|}{ Posttest } & \multirow[t]{2}{*}{$t$} & \multirow[t]{2}{*}{$\mathrm{d} f$} & \multirow[t]{2}{*}{$p$} \\
\hline & Mean & SD & Mean & SD & & & \\
\hline Social participation & 1.31 & 0.463 & 1.47 & 0.634 & -7.757 & 777 & 0.000 \\
\hline
\end{tabular}

TABLE 5 | Pretest/posttest differences within the control group in matters of social participation.

\begin{tabular}{|c|c|c|c|c|c|c|c|}
\hline \multirow[t]{3}{*}{ Factor } & \multicolumn{7}{|c|}{ Control group } \\
\hline & \multicolumn{2}{|c|}{ Pretest } & \multicolumn{2}{|c|}{ Posttest } & \multirow[t]{2}{*}{$t$} & \multirow[t]{2}{*}{$\mathrm{d} f$} & \multirow[t]{2}{*}{$p$} \\
\hline & Mean & SD & Mean & SD & & & \\
\hline Social participation & 1.29 & 0.469 & 1.34 & 0.543 & -2.658 & 357 & 0.008 \\
\hline
\end{tabular}

TABLE 6 | Differences between the EG and the CG in matters of social participation (posttest).

\begin{tabular}{llccccc}
\hline Factor & \multicolumn{2}{c}{$\begin{array}{c}\text { Levene's test for } \\
\text { equality of variances }\end{array}$} & & $\boldsymbol{T}$ & df & $\begin{array}{c}\text { Bilateral } \\
\text { sig. }\end{array}$ \\
\cline { 2 - 5 } & $\boldsymbol{F}$ & Sig. & & & \\
\hline Social participation & 6.123 & 0.013 & & -3.600 & 809.18 & 0.000 \\
\hline
\end{tabular}

\section{Civic and Social Competences}

Finally, regarding the evolution in the students' perception on the level of development of a set of civic and social competences, both groups experienced significant improvement (Tables 7, 8). Whereas all students increased their scores obtained in leadership, where at the start the numbers were at their lowest, those who participated in service learning, also improved their teamwork skills and the relationship with others.

In this scale no significant differences were found between the two groups at the end of the projects (Table 9). However, within the EG, there were numerous differences according to the students' profile and there we may list some relevant aspects in the four variables of our analysis:

- Regarding gender, women scored higher in most factors. More specifically, they differentiated themselves positively from the men with regard to pro-social behavior $\left(M_{\text {Women }}-M_{\text {Men }}=0.23, p=0.000\right)$, intercultural competence $\left(M_{\text {Women }}-M_{\text {Men }}=0.29\right.$, $p=0.000)$, and teamwork and relationship with others $\left(M_{\text {Women }}-M_{\text {Men }}=0.12, p=0.017\right)$. Nevertheless, in matters of leadership, it is men who scored higher $\left(M_{\text {Men }}-M_{\text {Women }}=0.12, p=0.011\right)$.

- With regard to the cycle of studies, just as in the case of the social participation scale, it is again the students in the first 2 years who had the advantage over their colleagues in matters of intercultural competence $\left(M_{\text {First cycle }}-M_{\text {Second cycle }}=0.13, p=0.004\right)$. 
TABLE 7 | Pretest/posttest differences within the experimental group in matters of civic and social competences.

\begin{tabular}{|c|c|c|c|c|c|c|c|}
\hline \multirow[t]{3}{*}{ Factor } & \multicolumn{7}{|c|}{ Experimental group } \\
\hline & \multicolumn{2}{|c|}{ Pretest } & \multicolumn{2}{|c|}{ Posttest } & \multirow[t]{2}{*}{$t$} & \multirow[t]{2}{*}{ df } & \multirow[t]{2}{*}{$p$} \\
\hline & Mean & SD & Mean & SD & & & \\
\hline Prosocial behavior & 4.39 & 0.419 & 4.41 & 0.430 & -1.409 & 754 & 0.159 \\
\hline Leadership & 3.69 & 0.557 & 3.82 & 0.599 & -7.440 & 774 & 0.000 \\
\hline $\begin{array}{l}\text { Intercultural } \\
\text { competence }\end{array}$ & 4.26 & 0.594 & 4.27 & 0.625 & -0.926 & 775 & 0.355 \\
\hline $\begin{array}{l}\text { Teamwork and } \\
\text { relationship with others }\end{array}$ & 4.20 & 0.549 & 4.23 & 0.583 & -2.267 & 780 & 0.024 \\
\hline
\end{tabular}

TABLE 8 | Pretest/posttest differences within the control group in matters of civic and social competences.

\begin{tabular}{|c|c|c|c|c|c|c|c|}
\hline \multirow[t]{3}{*}{ Factor } & \multicolumn{7}{|c|}{ Control group } \\
\hline & \multicolumn{2}{|c|}{ Pretest } & \multicolumn{2}{|c|}{ Posttest } & \multirow[t]{2}{*}{$T$} & \multirow[t]{2}{*}{$\mathrm{d} f$} & \multirow[t]{2}{*}{$p$} \\
\hline & Mean & SD & Mean & SD & & & \\
\hline Prosocial behavior & 4.39 & 0.395 & 4.40 & 0.390 & -0.565 & 348 & 0.572 \\
\hline Leadership & 3.63 & 0.575 & 3.76 & 0.558 & -5.025 & 354 & 0.000 \\
\hline $\begin{array}{l}\text { Intercultural } \\
\text { competence }\end{array}$ & 4.25 & 0.593 & 4.22 & 0.616 & 0.945 & 360 & 0.345 \\
\hline $\begin{array}{l}\text { Teamwork and } \\
\text { relationship with others }\end{array}$ & 4.21 & 0.517 & 4.20 & 0.571 & 0.141 & 357 & 0.888 \\
\hline
\end{tabular}

TABLE 9 | Differences between the EG and the CG in matters of civic and social competences (posttest).

\begin{tabular}{lcccccc}
\hline Factor & \multicolumn{2}{c}{$\begin{array}{c}\text { Levene's test for } \\
\text { equality of variances }\end{array}$} & & $T$ & df & $\begin{array}{c}\text { Bilateral } \\
\text { sig. }\end{array}$ \\
\cline { 2 - 3 } & $\boldsymbol{F}$ & Sig. & & & & \\
\hline $\begin{array}{l}\text { Prosocial behavior } \\
\text { Leadership }\end{array}$ & 0.854 & 0.356 & & -0.387 & 1,117 & 0.699 \\
$\begin{array}{l}\text { Intercultural } \\
\text { competence }\end{array}$ & 0.774 & 0.379 & & -1.655 & 1,136 & 0.098 \\
$\begin{array}{l}\text { Teamwork and } \\
\text { relationship with others }\end{array}$ & 0.953 & 0.329 & & -1.453 & 1,141 & 0.147 \\
\hline
\end{tabular}

- Regarding the area of study, it is the students of SocialLegal Sciences and Arts-Humanities who scored higher on intercultural competence ( $M_{\text {Social-Legal }}$ Sciences and Arts-Humanities $-M_{\text {Health }}$ and Engineering-Architecture $=0.20$, $p=0.003)$.

- Finally, there were also differences within the EG according to the previous participation in service activities promoted by the university. Specifically, those who had participated in such activities were the ones who achieved better results in matters of pro-social behavior $\left(M_{\text {Previous service }}-M_{\text {No previous service }}=0.08, p=0.038\right)$.

To finish with the interpretation of the results, Figure 1 is presented below with the intention of facilitating the understanding of the results obtained by both groups in the two applications of the questionnaire.

\section{DISCUSSION}

The study was based on the students' perception of the extent to which they think they have developed a certain set of competences which would be useful in terms of life development and employability. Let us then start by assessing the way in which they perceive their training in the university.

The first finding has to do with the positive appraisal the students, having participated in SL courses, make of the connection between their subject contents and real life. At this point, the results are close to what we found in the renowned work by Eyler and Giles (1999). There as well possibilities to apply the theoretical knowledge in real life translated into a greater motivation of the students involved in SL. This bears close similarity to the findings of Alonso et al. (2013), since the students stated that participation in SL influenced their motivation, given its practical character and the possibilities to establish relationships with real life in a similar professional environment. Neither should we forget the studies in which it is the teaching staff who give a positive appraisal to the possibility of applying the concepts of the instructed material in real contexts, resulting in an increase in the students' satisfaction (Weglarz and Seybert, 2004).

What we are showing in this study is precisely the fact that those students who participated in SL not only evolved positively in their own satisfaction with the training that they received, but also finished the projects differentiating themselves from their colleagues in this dimension. In this way, we give a solid backing to results coming from studies as the one carried out by Astin and Sax (1998), in which a group of students participating in SL also reported higher levels of satisfaction with the training received, explained in terms of relevance for real life and for professional exercise, which are aspects identical to those we have considered in our own study.

It was also demonstrated, that not only were the students involved in SL more satisfied with the education they receive in the university, but that their peers in the CG seem to reduce their levels of optimism - initially higher-with regard to said training (Moely et al., 2002a). It shouldn't come as a surprise, therefore, that there are studies in which more than $90 \%$ of the students declare that they would like to participate again in SL courses and would also recommend that their colleagues do the same (Folgueiras et al., 2013).

The last element around which students' perception of the university education revolved was the uncertainty about the future. In particular, our data showed that those who participated in SL did not manifest significant changes in this respect, although their colleagues involved in a more traditional learning dynamic, seemed to have more acute levels of uncertainty when the end of their studies was drawing near.

In this sense, even if they varied in the magnitude of the difference shown, the results we present here back those given by studies which demonstrate that SL does influence the 


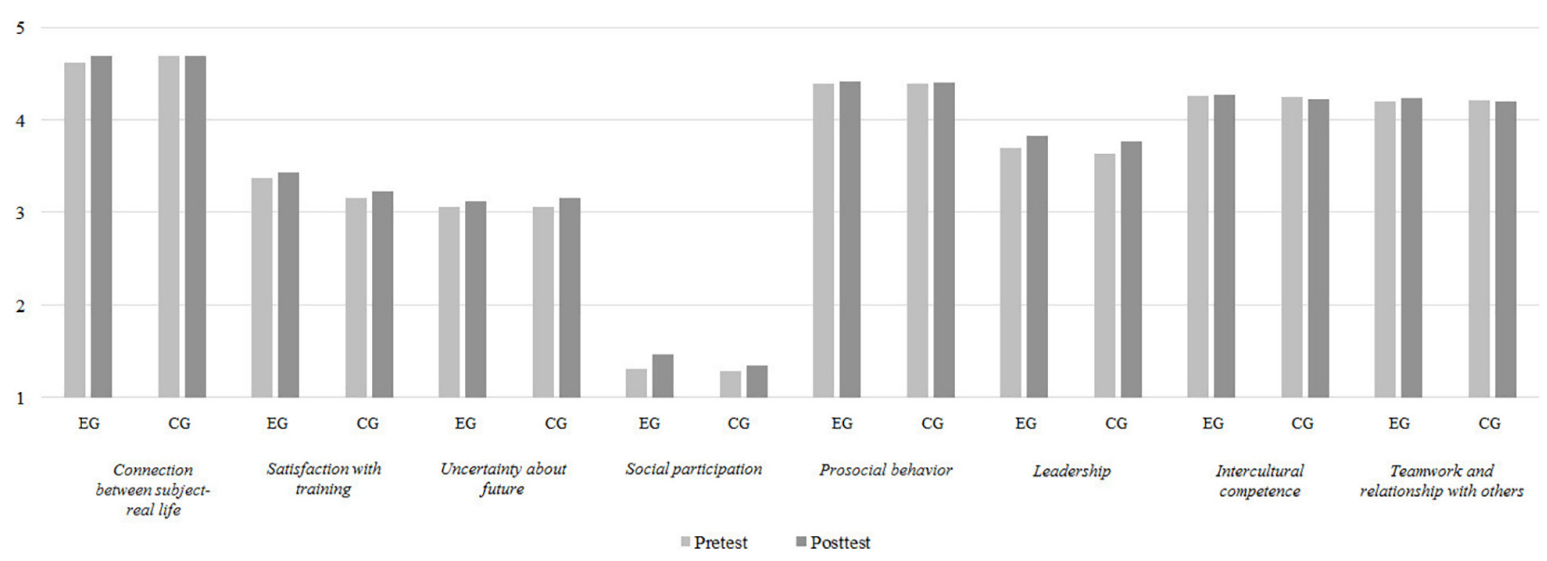

FIGURE 1 | Experimental group (EG) and control group (CG) scores in pretest and posttest. Source: own elaboration.

vocational development of students, seeming to contribute to their professional growth in terms of skill development (Weiss et al., 2016), with an orientative bias toward professional careers focused on service to the community (Astin et al., 2000). The most significant aspect is that it generates in the students some possibly more positive expectations regarding their future professional exercise (Aramburuzabala and García, 2012).

Once we have ascertained the degree of perceptive influence on the university training of students, we will approach the levels of social participation and of commitment to volunteering. That which is most clear in this particular aspect is that all students increased their levels of involvement in such activities, although those who participated in SL ended up doing it more assiduously.

This fact would, therefore, allow us to consider SL a methodology likely to connect the students with methods and issues rooted in community life, which promises some impact in the levels of social participation (Sotelino et al., 2019). The fact that it was shown that graduates who, during their student days, were involved in SL projects maintained non-negligible levels of participation in volunteer work is very significant (Fenzel and Peyrot, 2005; Moely and Ilustre, 2019). However, we cannot overlook the fact that our results point to a rather reduced involvement in social matters, which is more or less in keeping with what was already known about the Spanish student population (Jover, 2016).

Finally, changes have been observed in the levels of development of certain civic and social competences. The first of these is leadership, in which all students increased their scores, which does not allow us to associate this improvement with the participation in SL projects (Deeley, 2014; Moely and Ilustre, 2014). This is exactly the opposite of what was seen in the case of teamwork and relationship to others, where only the subjects from the EG significantly raised their scores. What becomes evident once more is that we are dealing with a methodology, with a marked interpersonal and relational component, given the reiteration of gains already observed in matters of teamwork (Hébert and Hauf, 2015), capacity of maintaining good relationships with others (García García and Sánchez Calleja, 2017), relational quality between professors and students (Alonso et al., 2013; Folgueiras et al., 2013) and certainly in the development of social capital (D’Agostino, 2010).

However, in the study we did not observe any significant results with regard to pro-social behavior and intercultural competence. This is in spite of the already recognized potential for SL to work on the pro-social disposition and civic competence of the students (Moely et al., 2002a; Celio et al., 2011), as well as on their intercultural competence and acceptance of diversity (Einfeld and Collins, 2008; Holsapple, 2012). It is, therefore, clear that on this scale no differences were detected between the two groups of students. Let us then go on to the last of the analyses carried out, that of the differences within the EG itself.

The first aspect is that this analysis revealed significantly better results in the case of women. More specifically, women scored higher in matters of how they appreciated the connection between subject contents and real life, the pro-social behavior, the intercultural competence, as well as teamwork and the relationship with others. As for men, they scored better in leadership. It is, therefore, clear that women are better when it comes to skills that are more strictly social; this is in line with the works conducted by McCarthy and Tucker (1999) and Moely and Ilustre (2019).

When considering the cycle of studies as variable for grouping the students who were involved in SL projects, we found that students of the first 2 years were the ones showing better levels of social participation in volunteer work as well as of intercultural competence. These data certainly did not support the idea expressed by Deeley (2015), who stated that SL could be a methodology more appropriate for students in the later years, invoking their better preparation for enrolling in this type of initiatives. In any case, the influence of SL on students in the earlier years was confirmed by other studies; they even showed that SL influenced decision making regarding the continuation of their university studies (Bringle et al., 2010; Reed et al., 2015).

We were also able to prove the appropriateness of devoting specific research efforts and initiatives to the different areas of study. In this regard, students of Social and Legal Sciences as well as students of Arts and Humanities scored far better in strictly social matters (social participation and intercultural competence), while those studying Health Sciences 
and Engineering and Architecture scored better in their satisfaction with the training they received. These results are in line with the position taken by Zlotkowski (2000), mainly that SL cannot be designed and implemented in the same way in every subject of study, which will surely be reflected in noncoincidental results among the students.

We conclude by referring to the influence of the fact of having participated in other service-activities promoted by the university on the results obtained by the students in SL courses. Those who had previously participated in these initiatives showed a more positive appraisal of the connection between studies and real life and higher levels of pro-social behavior. Certainly, this has already been shown in other studies, considering the effects of prior participation both in other SL projects (Brandes and Randall, 2011) and in volunteering (Astin et al., 2006). What these studies indicated, to be more precise, is that those students had both a better preparation and pre-disposition.

We believe that the results obtained allow us to answer the raised research question, since we were able to confirm that SL leads to a better level of development of important life competences for university students, even in comparison with their classmates who do not participate in this type of courses.

Even so, it must be acknowledged that the scope of this work is not unrelated to the social and cultural context, in which it is also important to understand the role of the university in each era. What this means is that the soft skills, under this or any other name, have received much more attention in the European Higher Education Area than in any other university structures, especially under the European Union's educational and employment policies (Clarke and Winch, 2006). Precisely for this reason, there is an urgent need for further studies, such as this, that aim to address with appropriate methodologies the adaptability of SL to the European university model, beyond the benefits that have been demonstrated in other contexts, as is the case of the United States.

In short, the extracted data contribute to the development of knowledge about the social and community value that active methodologies may have in the learning process of university students. We believe that the analysis carried out allows us to reinforce the role of learning which, due to not being specific to an academic discipline, has a positive impact on the personal, social, and professional progress of students. We should bear in mind that SL is not only about providing coverage for a better mastery of academic content, but also about making this content available for civic and social development in response to the needs of the environment. Thus, it allows working on the pedagogical principles that define the new educational model that is inherent to the EHEA, in which learning is focused on the student's work and the social and community dimension becomes increasingly important as a context of practice and enrichment for future graduates (González and Wagenaar, 2003; Santos Rego et al., 2020b).

\section{CONCLUSION}

It is the experience accumulated in the scientific study of $\mathrm{SL}$ in the educational system in general and in university education in particular, which further strengthens our belief in the importance of not considering this methodology as only a vehicle for achieving a more complete education of the student in academic terms. It should also be viewed as a substantial part of a pedagogical program with practical perspectives, whose functionality has been constantly associated with gains in cognitive and non-cognitive skills, but in any case is unequivocally linked to some dimensions of the social and professional life of students, obviously including university students.

With all proper precautions, the results of the present article demonstrate that this path of research is not unimportant, nor lacking not strong epistemic promises so as to continue emphasizing the need to constantly evaluate, with solid procedures, the competences likely to optimize the options for the future of the graduates.

In our study, the differences between the EG and the CG confirmed the narrative of a considerable effectiveness of SL, given that the EG evolved positively in more variables than the CG. It is a fact, very well observed here, that in the posttest stage the first of the groups distinguished itself for the better in a considerable number of variables. Therein lies the support that the data gave to the use of SL as a way to develop certain types of learning and certain generic competences for life and employment, in a better way than other, more conventional, methodologies.

Another aspect, which must not be overlooked just because it has already been noted in the literature relevant to this topic, is the connection of SL with academic learning, without forgetting the frequent complicity between generic and specific skills. It certainly occurs with the variables we studied, i.e., the perception of university education, indicating motivation or satisfaction because of its usefulness; the social participation stemming from the involvement in SL, synonymous to commitment and action; or the civic and social competences, among which the prosocial behavior or the teamwork are relevant. These are-we should recall-variables which mediate the students' academic performance (Mella et al., 2015).

But, in addition to that, our intention was to approach these competences as if they were a passport for a better development of those abilities which are more relevant for employability. We see how the first of the scales highlighted the training that is linked to real life, the usefulness of this training or the uncertainty about one's future after graduation. In addition, it is precisely in these areas that SL manifests itself as a methodology which marks strong connections between theory and practice, bringing the students closer to some of the professional scenarios awaiting them.

Owing to the second scale, we can also reiterate the potential SL has within the framework of an informal education planting the seeds of competences related to the employability (Santos Rego et al., 2018). It is in the last of the scales that the possible association between the civic-social competences and the employment of university students was clearly shown, beyond the classical contrast between an integral training along humanistic lines and a training based on a strictly mercantile logic (Santos Rego et al., 2020a). 
However, it would be rather naive to conclude that all the participating students showed an identical level of development. What we can infer from these results is the need to determine in advance, in certain variables, if we wish to optimize the implementation of the projects, as well as their impact in practical contexts. We are referring, among other things, to gender, to the academic year for which a SL project was designed, to previous participation in service activities, or the subject and field which we are dealing with. In line with very well-known references in the field (Zlotkowski, 2000), we advocate for further studies of SL tailored to the disciplinary structure of the various spheres of knowledge, with an emphasis on the students' vocational and professional dimensions.

We also need to emphasize a limitation of this article, which needs to be taken into account for the future. It is the attention which the pedagogical features of the projects deserve, especially if concerted efforts will be made to define quality criteria for them. What this can and must require is a closer monitoring of the experiences, in order to consider, on-site, keys of educational intervention likely to result in differences in the students' learning gradients (the quality and depth of reflection and the students' participation in the conception and implementation of the project would be some of them).

Coming to the end of this article and in a similar line of methodological self-criticism, we are displeased by the impossibility to have chance to determine the composition of the groups (the experimental and the control one) together with their allocation to the treatment (participation in the SL program). It is obvious that a study may be affected by the circumstance and/or type of participation (volunteer vs. mandatory) of the students.

\section{REFERENCES}

Alonso, I., Arandia, M., Martínez Domínguez, I., Martínez Domínguez, B., and Gezuraga, M. (2013). El aprendizaje-servicio en la innovación universitaria. Una experiencia realizada en la formación de educadoras y educadores sociales. Revista Internacional de Educación para la Justicia Social 2, 195-216. doi: 10.4995/redu.2018.9127

Andrews, J., and Higson, H. (2008). Graduate employability, 'soft skills' versus 'hard' business knowledge: A European study. Higher Education in Europe 33, 411-422. doi: 10.1080/03797720802522627

Aramburuzabala, P., and García, R. (2012). El aprendizaje-servicio en la formación de maestros. Revista del Congrés Internacional de Docència Universitària $i$ Innovació 1, 1-15.

Astin, A. W., and Sax, L. J. (1998). How undergraduates are affected by service participation? J. Coll. Stud. Dev. 39, 251-263.

Astin, A. W., Vogelgesang, L. J., Ikeda, E. K., and Yee, J. A. (2000). How servicelearning affects students. Los Ángeles, CA: Higher Education Research Institute.

Astin, A. W., Vogelgesang, L. J., Misa, K., Anderson, J., Denson, N., Jayamukar, U., et al. (2006). Understanding the effects of servicelearning: A study of students and faculty. Available online at: https: //www.researchgate.net/publication/266456683_Understanding_the_Effects_ of_Service-Learning_A_Study_of_Students_and_Faculty (accessed July 28, 2020)

Bancino, R., and Zevalkink, C. (2007). Soft Skills: The New Curriculum for HardCore Technical Professionals. Techniques: Connecting Education and Careers $82,20-22$.

Brandes, K., and Randall, G. K. (2011). Service learning and civic responsibility: Assessing aggregate and individual level change. International Journal of Teaching and Learning in Higher Education 23, 20-29.

\section{DATA AVAILABILITY STATEMENT}

The raw data supporting the conclusions of this article will be made available by the authors, without undue reservation.

\section{ETHICS STATEMENT}

The studies involving human participants were reviewed and approved by Bioethics Committee of the University of Santiago de Compostela (Spain). The patients/participants provided their written informed consent to participate in this study.

\section{AUTHOR CONTRIBUTIONS}

MS and IM collected, analysed the data, and wrote the manuscript. $\mathrm{CN}$ and $\mathrm{VV}$ contributed to the theoretical framework and the discussion of the results obtained. All the authors contributed to the article and approved the submitted version.

\section{FUNDING}

This work is derived from two projects of the Spanish State Program of Research, Development and Innovation oriented toward the Challenges of Society (EDU2013-41687-R and EDU2017-82629-R) and a Research Network of the Spanish State Program for Knowledge Generation and Scientific and Technological Strengthening of the R\&D\&I System (EDU201790651-REDT)_http://www.usc.es/apsuni/.

Bringle, R. G., and Clayton, P. H. (2012). "Civic education through service learning: what, how, and why?" in Higher education and civic engagement. Comparative perspectives, eds L. McIlrath, A. Lyons, and R. Munck (New York, NY: Palgrave Macmillan), 101-124. doi: 10.1057/9781137074829 7

Bringle, R. G., Hatcher, J. A., and Muthiah, R. N. (2010). The role of servicelearning on the retention of first-year students to second year. Michigan Journal of Community Service Learning 16, 38-49.

Butin, D. W. (2003). Of what use is it? Multiple conceptualizations of service learning within education. Teach. Coll. Rec. 105, 1674-1692. doi: 10.1046/j. 1467-9620.2003.00305.x

Campus Compact. (2015). Preparing to accelerate change: understanding our starting line. 2015 annual member survey. Available online at: https://compact. org/resource-posts/2015-member-survey-executive-summary/ (Accessed July $28,2020)$.

Celio, C. I., Durlak, J., and Dymnicki, A. (2011). A meta-analysis of the impact of service-learning on students. Journal of Experiential Education 34, 164-181. doi: 10.5193/jee34.2.164

Clarke, L., and Winch, C. (2006). A European skills framework?-but what are skills? Anglo-Saxon versus German concepts. Journal of Education and Work 19, 255-269. doi: 10.1080/13639080600776870

Cohen, A. (2020). Teaching to teach civics in fragile times: a conceptual framework. Eur. J. Teach. Educ. 44, 1-22. doi: 10.1080/02619768.2020.174 8880

Commission of the European Communities. (2003). The role of universities in the Europe of knowledge. Available online at: https:/eur-lex.europa.eu/legalcontent/EN/TXT/HTML/?uri=LEGISSUM:c11067\&from=EN (accessed July $28,2020)$.

Council of the European Union. (2010). Council conclusions of 11 May 2010 on competences supporting lifelong learning and the 'new skills for new jobs' 
initiative. Available online at: https://eur-lex.europa.eu/legal-content/EN/TXT/ PDF/?uri=CELEX:52010XG0526(02)\&from=ES (accessed July 28, 2020).

Cudeck, R., and Browne, M. W. (1983). Cross-validation of covariance structures. Multivariate Behav. Res. 18, 147-167. doi: 10.1207/s15327906mbr1802_2

D'Agostino, M. J. (2010). Measuring social capital as an outcome of service learning. Innovative Higher Education 35, 313-328. doi: 10.1007/s10755-0109149-5

Deeley, S. J. (2014). Summative co-assessment: A deep learning approach to enhancing employability skills and attributes. Active Learning in Higher Education 15, 39-51. doi: 10.1177/1469787413514649

Deeley, S. J. (2015). Critical perspectives on service-learning in higher education. Basingstoke: Palgrave Macmillan.

Delanty, G. (2003). Ideologies of the knowledge society and the cultural contradictions of higher education. Policy Futures in Education 1, 71-82. doi: 10.2304/pfie.2003.1.1.9

Einfeld, A., and Collins, D. (2008). The relationships between service-learning, social justice, multicultural competence, and civic engagement. J. Coll. Stud. Dev. 49, 95-109. doi: 10.1353/csd.2008.0017

Etzkowitz, H., Ranga, M., and Dzisah, J. (2012). Whither the university? The Novum Trivium and the transition from industrial to knowledge society. Soc. Sci. Inf. Sci. Soc. 51, 143-164. doi: 10.1177/0539018412437099

Eyler, J., and Giles, D. E. (1999). Where's the learning in service-learning?. San Francisco, CA: Jossey-Bass.

Fenzel, L. M., and Peyrot, M. (2005). Comparing college community participation and future service behaviors and attitudes. Michigan Journal of Community Service Learning 12, 23-31.

Folgueiras, P., Luna, E., and Puig, G. (2013). Aprendizaje y servicio: estudio del grado de satisfacción de estudiantes universitarios. Rev. Educ. 362, 159-185. doi: 10.4438/1988-592X-RE-2011-362-157

Furco, A. (1995). Evaluation System for Experiential Education Programs (ESEE). Available online at: https://digitalcommons.unomaha.edu/slceeval/43/ (accessed July 28, 2020).

García García, M., and Sánchez Calleja, L. (2017). El aprendizaje servicio y el desarrollo de las competencias emocionales en la formación inicial del profesorado. Contextos Educativos 20, 127-145. doi: 10.18172/con.2991

Gonsalves, J., Metchik, E. Y., Lynch, C., Belezos, C. N., and Richards, P. (2019). Optimizing service-learning for self-efficacy and learner empowerment. Michigan Journal of Community Service Learning 25, 19-41. doi: 10.3998/ mjcsloa.3239521.0025.202

González, J., and Wagenaar, R. (2003). Tuning Educational Structures in Europe. Bilbao: Universidad de Deusto.

Hébert, A., and Hauf, P. (2015). Student learning through service learning: Effects on academic development, civic responsibility, interpersonal skills and practical skills. Active Learning in Higher Education 16, 37-49. doi: 10.1177/ 1469787415573357

Heckman, J. J., and Kautz, T. (2012). Hard evidence on soft skills. Labour Econ. 19, 451-464. doi: 10.1016/j.labeco.2012.05.014

Holsapple, M. A. (2012). Service-learning and student diversity outcomes: Existing evidence and directions for future research. Michigan Journal of Community Service Learning 18, 5-18.

Jagla, V., and Tice, K. (Eds.) (2019). Educating teachers \& tomorrow's students through service-learning pedagogy. Charlotte, NC: Information Age Publishing.

Jover, G. (2016). "Aprendizaje y pragmatismo universitario en la sociedad del conocimiento," in Sociedad del conocimiento. Aprendizaje e innovación en la universidad, ed. M. A. Santos Rego (Madrid: Biblioteca nueva), $23-40$.

Lane, R. E. (1966). The decline of politics and ideology in a knowledgeable society. Am. Sociol. Rev. 31, 649-662. doi: 10.2307/2091856

Lazarus, A. (2013). Soften up: the importance of soft skills for job success. Physician Executive 39, 40-45.

Levesque-Bristol, C., and Richards, K. A. (2014). Evaluating civic learning in service-learning programs: creation and validation of the Public Affairs ScaleShort Survey (PAS-SS). Journal of Public Affairs Education 20, 413-428. doi: 10.1080/15236803.2014.12001796

Markus, G. B., Howard, J., and King, D. C. (1993). Integrating community service and classroom instruction enhances learning: results from an experiment. Educ. Eval. Policy Anal. 15, 410-419. doi: 10.3102/01623737015004410
Matteson, M., Anderson, L., and Boyden, C. (2016). Soft Skills: A phrase in search of meaning. Portal Libraries and the Academy 16, 71-88. doi: 10.1353/pla.2016. 0009

McCarthy, A. M., and Tucker, M. L. (1999). Student attitudes toward servicelearning: implications for implementation. Journal of Management Education 23, 554-573. doi: 10.1177/105256299902300511

McIlrath, L. (2012). "Community perspective on university partnership - Prodding the sacred cow," in Higher education and civic engagement. Comparative perspectives, eds L. McIlrath, A. Lyons, and R. Munck (New York, NY: Palgrave Macmillan), 139-154. doi: 10.1057/9781137074829_9

Mella, I. (2019). Aprendizaje-servicio y rendimiento académico del alumnado universitario. La evaluación de un programa. Ph.D. thesis, University of Santiago de Compostela, Santiago de Compostela.

Mella, I., Santos Rego, M. A., and Malheiro, X. M. (2015). Aprendizaje-servicio y rendimiento académico del alumnado universitario. Revista de Estudios e Investigación en Psicología y Educación 12, 35-39. doi: 10.17979/reipe.2015.0. 12.569

Mitchell, G., Skinner, L., and White, B. (2010). Essential soft skills for success in the twenty-first century workforce as perceived by business educators. Delta Pi Epsilon Journal 52, 43-53.

Moely, B. E., and Ilustre, V. (2014). The impact of service-learning course characteristics on university students' learning outcomes. Michigan Journal of Community Service Learning 21, 5-16.

Moely, B. E., and Ilustre, V. (2019). Service involvement and civic attitudes of university alumni: later-correlates of required public service participation during college. Michigan Journal of Community Service Learning 25, 30-42. doi: 10.3998/mjcsloa.3239521.0025.103

Moely, B. E., McFarland, M., Miron, D., Mercer, S., and Ilustre, V. (2002a). Changes in college students' attitudes and intentions for civic involvement as a function of service-learning experiences. Michigan Journal of Community Service Learning 9, 18-26.

Moely, B. E., Mercer, S. H., Ilustre, V., Miron, D., and McFarland, M. (2002b). Psychometric properties and correlates of the Civic Attitudes and Skills Questionnaire (CASQ): A measure of students' attitudes related to servicelearning. Michigan Journal of Community Service Learning 8, 15-26.

Naval, C., and Arbués, E. (2016). The effects of the economic crisis on active citizenship among young people in Spain, and what we can do about it through civic education in Universities. Citizenship, Teaching and Learning 11, 305-314. doi: 10.1386/ctl.11.3.305_1

Naval, C., and Arbués, E. (Eds.) (2018). Hacer la Universidad en el espacio social. Pamplona: EUNSA.

Naval, C., García, R., Puig, J., and Santos Rego, M. A. (2011). Ethical and civic education and the social commitment of university students. Encount. Educ. 12, 77-91. doi: 10.24908/eoe-ese-rse.v12i0.3174

Opazo, H., Aramburuzabala, P., and Ramírez, C. (2018). Emotions related to Spanish student-teachers' changes in life purposes following service-learning participation. J. Moral Educ. 47, 217-230. doi: 10.1080/03057240.2018.1438992

Opazo, H., Ramírez, C., García-Peinado, R., and Lorite, M. (2015). La ética en el aprendizaje-servicio: Un meta-análisis a partir de Education Resources Information Center (ERIC). Profesorado 19, 144-175.

Pike, G. R., Bringle, R. G., and Hatcher, J. A. (2014). Assessing civic engagement at Indiana University-Purdue University Indianapolis. New Directions for Institutional Research 162, 87-97. doi: 10.1002/ir.20081

Reed, S. C., Rosenberg, H., Statham, A., and Rosing, H. (2015). The effect of community service learning on undergraduate persistence in three institutional contexts. Michigan Journal of Community Service Learning 21, 22-36.

Santos Rego, M. A. (Ed.) (2016). Sociedad del conocimiento. Aprendizaje e Innovación en la Universidad. Madrid: Biblioteca nueva.

Santos Rego, M. A., Ferraces, M. J., Mella, I., and Vázquez-Rodríguez, A. (2020a). University, civic-social competences, and the labour market. Rev. Esp. Pedagog. 78, 213-232. doi: 10.22550/REP78-2-2020-06

Santos Rego, M. A., and Lorenzo, M. (Eds.) (2018). A guide for the institutionalization of service-learning at university level. Santiago de Compostela: Servizo de Publicacións e Intercambio Científico da Universidade de Santiago de Compostela, doi: 10.15304/op.2018.1165

Santos Rego, M. A., Lorenzo, M., and Mella, I. (2020b). El aprendizaje-servicio y la educación universitaria. Hacer personas competentes. Barcelona: Octaedro. 
Santos Rego, M. A., Lorenzo, M., and Vázquez Rodríguez, A. (2018). Educación no formal y empleabilidad de la juventud. Madrid: Síntesis.

Sotelino, A., Mella, I., and Rodríguez, M. A. (2019). El papel de las entidades cívico-sociales en el aprendizaje-servicio. Sistematizando la participación del alumnado en el tercer sector. Teor. Educ. 31, 197-219. doi: 10.14201/teri.20156

Steinberg, K. S., Hatcher, J. A., and Bringle, R. G. (2011). Civic-minded graduate: a north star. Michigan Journal of Community Service Learning 18, 19-33.

Succi, C., and Canovi, M. (2019). Soft skills to enhance graduate employability: comparing students and employers' perceptions. Stud. High. Educ. 45, 1-14. doi: 10.1080/03075079.2019.1585420

Thamwipat, K., Princhankol, P., Yampinij, S., and Meejaleurn, S. (2018). The development of media activities by undergraduate students in order to promote agricultural tourism community enterprise according to the principles of social service learning and community-based leaning. International Education Studies 11, 38-45. doi: 10.5539/ies.v11n5p38

Touloumakos, A. (2011). Now you see it now you don't: the gap between the characteristics of soft skills in Policy and in Practice. Ph.D. thesis, University of Oxford, Oxford.

Ugarte, C., and Naval, C. (2010). La formación política de los alumnos de educación secundaria. Descripción y valoración de programas de service-learning en los Estados Unidos y la Unión Europea. Edetania 37, 109-128.

UNESCO. (1998). World Conference on Higher Education. Higher education in the twenty-first century: Vision and action. Available online at: https://unesdoc. unesco.org/ark:/48223/pf0000116428 (accessed July 28, 2020).

Välimaa, J., and Hoffman, D. (2008). Knowledge society discourse and higher education. High. Educ. 56, 265-285. doi: 10.1007/s10734-008-9123-7

Watson, R. M., Willford, J. D., and Pfeifer, M. A. (2018). A cultured learning environment: implementing a problem- and service-based microbiology capstone course to assess process- and skill-based learning objectives Interdisciplinary Journal of Problem-based Learning 12, 8. doi: 10.7771/15415015.1694

Weglarz, S. G., and Seybert, J. A. (2004). Participant perceptions of a community college service-learning program. Community College Journal of Research and Practice 28, 123-132. doi: 10.1080/1066892049025 3618

Weiss, D., Hajjar, E. R., Giordano, C., and Joseph, A. S. (2016). Student perception of academic and professional development during an introductory servicelearning experience. Currents in Pharmacy Teaching and Learning 8, 833-839. doi: 10.1016/j.cptl.2016.08.016

Wye, C., and Lim, Y. (2009). Perception differential between employers and undergraduates on the importance of employability skills. International Education Studies 2, 95-105. doi: 10.5539/ies.v2n1p95

Zlotkowski, E. (2000). Service-learning research in the disciplines. Michigan Journal of Community Service Learning Special Volume 1, 61-67.

Conflict of Interest: The authors declare that the research was conducted in the absence of any commercial or financial relationships that could be construed as a potential conflict of interest.

Copyright () 2021 Santos Rego, Mella Núñez, Naval and Vázquez Verdera. This is an open-access article distributed under the terms of the Creative Commons Attribution License (CC BY). The use, distribution or reproduction in other forums is permitted, provided the original author(s) and the copyright owner(s) are credited and that the original publication in this journal is cited, in accordance with accepted academic practice. No use, distribution or reproduction is permitted which does not comply with these terms. 